NBER WORKING PAPER SERIES

\title{
FINANCIAL LITERACY AND PLANNING: IMPLICATIONS FOR RETIREMENT WELLBEING
}

\author{
Annamaria Lusardi \\ Olivia S. Mitchell \\ Working Paper 17078 \\ http://www.nber.org/papers/w17078
NATIONAL BUREAU OF ECONOMIC RESEARCH
1050 Massachusetts Avenue \\ Cambridge, MA 02138 \\ May 2011
}

\begin{abstract}
The research reported herein was pursuant to a grant from the US Social Security Administration (SSA) funded as part of the Retirement Research Consortium (RRC) and the Pension Research Council/Boettner Center at the Wharton School. Without implicating them, we are grateful for comments provided by Alberto Alesina, Rob Alessie, Maristella Botticini, John Campbell, Andrew Caplin, Sewin Chan, Gary Engelhardt, Alan Gustman, Mike Hurd, Arie Kapteyn, Mauro Mastrogiacomo, Mary Beth Ofstedal, William Rodgers, Chris Snyder, Maarten van Rooij, Arthur van Soest, and Steve Utkus. Helpful suggestions were offered by participants at conference at Dartmouth, Harvard, Rand, the NBER, the Retirement Research Consortium, the Dutch Central Bank, and the American Economic Association. Mark Christman and Jason Beeler provided excellent research assistance. Opinions and errors are solely those of the authors and not of the institutions with whom the authors are affiliated. Findings and conclusions do not represent the views of the SSA, any agency of the Federal Government, the RRC, or the National Bureau of Economic Research.
\end{abstract}

NBER working papers are circulated for discussion and comment purposes. They have not been peerreviewed or been subject to the review by the NBER Board of Directors that accompanies official NBER publications.

(C) 2011 by Annamaria Lusardi and Olivia S. Mitchell. All rights reserved. Short sections of text, not to exceed two paragraphs, may be quoted without explicit permission provided that full credit, including (C) notice, is given to the source. 
Financial Literacy and Planning: Implications for Retirement Wellbeing Annamaria Lusardi and Olivia S. Mitchell

NBER Working Paper No. 17078

May 2011

JEL No. D91

\begin{abstract}
$\underline{\text { ABSTRACT }}$
Relatively little is known about why people fail to plan for retirement and whether planning and information costs might affect retirement saving patterns. This paper reports on a purpose-built survey module on planning and financial literacy for the Health and Retirement Study which measures how people make financial plans, collect the information needed to make these plans, and implement the plans. We show that financial illiteracy is widespread among older Americans, particularly women, minorities, and the least educated. We also find that the financially savvy are more likely to plan and to succeed in their planning, and they rely on formal methods such as retirement calculators, retirement seminars, and financial experts, instead of family/relatives or co-workers. These results have implications for targeted financial education efforts.
\end{abstract}

\author{
Annamaria Lusardi \\ George Washington School of Business \\ 2201 G Street, NW \\ Washington, DC 20052 \\ and NBER \\ alusardi@gwu.edu \\ Olivia S. Mitchell \\ University of Pennsylvania \\ Wharton School \\ 3620 Locust Walk, St 3000 SH-DH \\ Philadelphia, PA 19104-6302 \\ and NBER \\ mitchelo@wharton.upenn.edu
}




\section{Introduction}

Most older Americans are not at all confident about the efficacy of their efforts to save for retirement, and in fact one-third of adults in their 50s have failed to develop any kind of retirement saving plan at all (Lusardi 1999, 2003; Yakoboski and Dickemper, 1997). What explains this low level of retirement preparedness? Why do people do such a poor job when it comes to designing and carrying out retirement saving plans? In this paper we explore the hypothesis that poor planning may be a primary result of financial illiteracy. That is, we evaluate whether those who report that they are unable to plan for retirement and/or who cannot carry out their retirement saving plans are also those who are' least aware of fundamental economic concepts driving economic wellbeing over the life cycle.

While several prior studies offer suggestions about why people fail to plan for retirement, few examine the roles that planning and information costs might play in affecting retirement saving decisions. Others have offered evidence on related topics; for instance Calvert, Campbell, and Sodini (2007) show that more sophisticated households are more likely to buy equities and invest more efficiently, ${ }^{1}$ and Hilgerth, Hogarth, and Beverly (2003) and Lusardi and Mitchell (2009) demonstrate strong links between financial knowledge and financial behavior. Our contribution reports on a special module on planning and financial literacy we designed for the 2004 Health and Retirement Study (HRS) which allows us to investigate how workers make their saving decisions, how they collect the information for making these decisions, and whether they possess the financial literacy needed to make these decisions. Using the responses to this survey, we argue that 
lack of literacy and financial sophistication are critical because they have important consequences for lifetime wellbeing.

\section{Methods and Data}

The conventional economic framework used to model consumption and saving decisions posits that rational and foresighted consumers derive utility from consumption and leisure over the lifetime. In its simplest format, the consumer's problem is modeled as in terms of lifetime expected utility or the expected value of the sum of per-period utility $\mathrm{U}\left(\mathrm{c}_{\mathrm{j}}\right)$ discounted to the present (with discount factor $\beta$ ), multiplied by the probability of survival $p_{j}$ from the worker's current age $\mathrm{j}$ to the oldest possible lifetime D:

$$
E\left[\sum_{j=s}^{D} \beta^{j-s} U\left(c_{j}\right)\right] .
$$

Per period assets and consumption $\left(a_{j}\right.$ and $\left.c_{j}\right)$ are determined endogenously by maximizing this function subject to an intertemporal budget constraint; here $\mathrm{e}_{\mathrm{j}}$ is labor earnings, $\mathrm{ra}_{\mathrm{j}}$ represents the household's returns on assets $\mathrm{a}_{\mathrm{j}}$, and SS and PP represent the household's Social Security benefits and pensions which depend on the worker's retirement (R) age:

$$
\begin{aligned}
& \left.y_{j}=e_{j}+r a_{j}, j \in\{S, \ldots, R-1)\right\} \\
& \text { and } \\
& y_{j}=S S_{j}(R)+P P_{j}(R)+r a_{j}, j \in[R, \ldots, D] .
\end{aligned}
$$

Furthermore consumption depends on income, assets, and benefits so that:

$$
\begin{aligned}
& c_{j}+a_{j+1}=y_{j}+a_{j}, j \in[S, \ldots, R-1] \text { before retirement (R), and } \\
& c_{j}+a_{j+1}=y_{j}+a_{j}, j \in[R, \ldots, D] \text { from retirement to death (D). }{ }^{2}
\end{aligned}
$$


In other words, the economic model posits that the consumer has expectations regarding prospective survival probabilities, discount rates, investment returns, earnings, pensions and Social Security benefits, and inflation. Further, the consumer is assumed to use that information to formulate and execute optimal consumption, work, and saving plans.

This formulation makes it clear that saving for retirement requires substantial information and financial literacy, as well as the tools to plan and implement retirement saving plans. But whether "real people” can meet this challenge is a topic of substantial current interest, and it is particularly important in view of the trend have workers take responsibility to save, manage their pension investments, and draw down their retirement assets in a self-managed retirement environment. To further investigate the links between the sources of information on which households rely, financial literacy, and planning, we designed a special module on retirement planning to assess levels of financial literacy along with consumers' efforts to budget, calculate, and develop retirement saving plans. We implement this in the context of the Health and Retirement Study (HRS), a nationally representative longitudinal dataset of Americans over the age of 50. This survey, conducted every two years since 1992, is designed to address these questions by tracking health, assets, liabilities, and patterns of wellbeing in older households. The core survey consists of a 90-minute core questionnaire administered to age-eligible respondents and their spouses. In addition, our special financial literacy and planning module included three questions on financial literacy, as follows:

- $\quad$ Suppose you had \$100 in a savings account and the interest rate was 2\% per year. After 5 years, how much do you think you would have in the account if you left the money to grow: more than $\$ 102$, exactly $\$ 102$, less than $\$ 102$ ? 
- Imagine that the interest rate on your savings account was $1 \%$ per year and inflation was $2 \%$ per year. After 1 year, would you be able to buy more than, exactly the same as, or less than today with the money in this account?

- Do you think that the following statement is true or false? "Buying a single company stock usually provides a safer return than a stock mutual fund."

The first two questions we refer to as the "Compound Interest" and "Inflation" items, and they indicate whether respondents command the key economic concepts fundamental to saving. The third question, which we dub "Stock Risk," evaluates knowledge of risk diversification, crucial to informed investment decisions.

We also ask respondents to how they calculate retirement saving needs. To do so, we replicate a question on whether people plan for retirement asked by EBRI in its Retirement Confidence Survey and in TIAA-CREF surveys (Ameriks, Caplin and Leahy 2003; EBRI 1996, 2001). We also ask whether people ever assessed their retirement saving needs and what followed from such assessment. The three HRS modular questions on retirement planning are as follows:

- Have you ever tried to figure out how much your household would need to save for retirement?

- Did you develop a plan for retirement saving?

- How often were you able to stick to this plan: Would you say always, mostly, rarely, or never?

Last we assess what tools people use to devise and carry out their retirement saving plans. Specifically, we inquire whether respondents contact friends, relatives, or experts, and whether they use retirement calculators. Also we ask whether respondents track their spending and set spending budgets. The specific planning tools questions are as follows:

- Tell me about the ways you tried to figure out how much your household would need.

o Did you talk to family and relatives? 
o Did you talk to co-workers or friends?

o Did you talk to co-workers or friends?

o Did you use calculators or worksheets that are computer or Internet-based?

o Did you consult a financial planner or advisor or an accountant?

- How often do you keep track of your actual spending: would you say always, mostly, rarely, or never?

- How often do you set budget targets for your spending: would you say always, mostly, rarely, or never?

Using respondents' answers to these questions, along with information of their sociodemographic characteristics, we can assess the prevalence of financial literacy, retirement calculations, and the planning tools people deploy to devise and execute their plans. In addition, we determine whether those who lack knowledge of basic economic concepts also seem to be those who have particular difficulty devising plans and carrying them out in practice. In what follows, we offer both tabular and multivariate analysis of the data, so as to evaluate whether those who are more financially literate are also more likely to plan and be successful planners.

\section{Financial Literacy Results}

Our first set of findings on financial literacy among this nationally representative sample of older Americans is reported in Panel A of Table 1, where we see that only twothirds of the respondents understand compound interest. This is a discouraging finding inasmuch as this generation in its 50's and 60's has made many important financial decisions over its lifetime. More of the respondents, three-quarters, can answer the inflation question correctly and understand they would be able to buy less after a year if the interest rate was 1 percent and inflation 2 percent. Yet only half of the respondents know that holding a single company stock implies a riskier return than a stock mutual fund. It is also of interest to distinguish between those who can give a correct answer, 
versus those giving either an incorrect answer or saying they “don’t know” (DK).

Interestingly, the proportion of incorrect/DK responses varies according to the question.

For example, only 9 percent did not know about interest compounding, but more than onefifth (22 percent) gave an incorrect answer. On the inflation question, 10 percent did not know, while 13 percent gave a wrong answer. The question about stock risk elicited the most DKs: one-third (34 percent) of the sample did not know, while a smaller fraction (13 percent) gave a wrong answer.

Table 1 here

Inasmuch as the first two questions are crucial to financial numeracy, it is disturbing that only slightly over half (56 percent) of the sample gets both questions right (see Panel B). Also disturbing is the fact that only one-third (34 percent) of respondents can correctly answer all three questions. Another interesting finding is that the "DK" responses are highly correlated: that is, financial illiteracy is systematic across areas examined. For instance, there is a 70 percent correlation between those who cannot answer both the interest compounding question and the inflation question. Erroneous answers are more scattered, with mistakes having a correlation of only 11 percent.

These results reinforce other U.S. findings on older respondents (c.f. Bernheim 1995, 1998; Hogarth and Hilgerth 2002; Moore 2003; and Lusardi and Mitchell 2007b, 2007c). These authors tend to concur that such individuals often fail to understand key financial concepts particularly relating to bonds, stocks, mutual funds, and the working of compound interest; they also report that these people often do not understand loans (and in particular, mortgages). ${ }^{3}$ The same is true of younger Americans: the National Council on Economic Education (NCEE 2005) study of high school students and working-age adults 
in 2005 revealed a widespread lack of knowledge of fundamental economic concepts. Similar results for US high school students are reported by Mandell (2004) and young adults (Lusardi, Mitchell, and Curto 2010). ${ }^{4}$ Clearly the news is far from positive: Americans’ financial literacy levels are low.

Who Is Financially Literate? Next we evaluate the extent of heterogeneity in financial knowledge across demographic groups. Specifically, we are interested in whether knowledge patterns differ by race/ethnicity and education, as depicted in Figure1. A first point to note is the differences in knowledge between Whites, Blacks, and Hispanics. ${ }^{5}$ Specifically, fewer than half of the Hispanics can answer correctly the interest compounding question, and a sizable fraction of the remainder stated they did not know the answer. This is a potentially important result in view of the fact that many Hispanics tend to be unbanked and do not hold checking accounts (Hogarth, Anguelov, and Lee 2004). A similar pattern emerges with the question about inflation, where again Hispanics are least likely to answer correctly. As far as risk diversification is concerned, Hispanics and Blacks both display difficulty answering this question: only one-third (37 percent) of the Blacks responded correctly, and over 40 percent did not know the answer to this question. This may shed further light on why so many Blacks do not hold stocks (Haliassos and Bertaut 1995).

Figure 1 here

Differences in financial knowledge across education groups are represented in Figure2, and the patterns confirm expectations that financial literacy is highly and positively correlated with schooling. Most importantly, financial illiteracy is most acute for those with less than a high school degree, and fewer than one-third of respondents with 
only elementary education could correctly answer the question about interest compounding (another third did not know). The prevalence of correct answers to the interest compounding question rises with education, while the proportion of both incorrect answers and DKs falls. A similar pattern characterizes answers to the inflation question, where those lacking a high school education are much more often incorrect or cannot answer the question. Turning to the risk diversification question, only those with at least a college degree display a high proportion of correct answers, though even here, almost a third of these did not know the answer or answered incorrectly to this question. Among the less-educated, the proportion of DK was particularly high; over half of those with less than high school education reported they did not know the answer to these questions. Figure 2 here

Figure 3 reveals response patterns by sex, where the results confirm that women are generally less financially knowledgeable than men (c.f. Lusardi and Mitchell 2008). Concerning risk diversification, women are less likely to respond correctly to the question compared to men, and are more likely to not know the answer rather than answering incorrectly. Also fewer women can answer all questions correctly compared to men. Figure 3 here

For brevity, we merely summarize other financial literacy results for along other dimensions. Findings worth highlighting including the fact that the leading edge of the Baby-Boomers (age 51-56 in 2004) was much less knowledgeable about inflation, perhaps a result of their limited historical exposure to inflation or the fact they were in their 20s in the high inflation period during the 1970s and early 1980s. 


\section{Findings for Retirement Planning}

Next we turn an assessment of some of the other predictions of the canonic economic model, including the hypothesis that people look ahead and calculate how much they need to save for retirement. To this end, our HRS modules asks respondents whether they ever tried to figure out how much they need to save for retirement and Table 2 reports the results. Somewhat discouragingly, fewer than one-third of the sample respondents (31 percent) indicated that they actually attempted to do a retirement saving calculation; these we call the Simple Planners. The small size of this group confirms summaries of older HRS waves where many people indicated they had given little thought to retirement even when they were just a few years away from leaving the workforce (Lusardi 1999, 2002, 2003). Our results also confirm a widespread lack of retirement planning, even among the educated (Yakobosky and Dickempers 1997; Ameriks, Caplin and Leahy 2004). It is also consistent with work by Mitchell (1988) and Gustman and Steinmeier (1999) who found that workers seem to know very little about their Social Security and pension benefits, two of the most important components of retirement wealth. In fact, close to half of workers in the HRS analyzed by Gustman and Steinmeier (2004) could not report their type of pension plan, and an even larger portion was ignorant of future Social Security benefits. ${ }^{6}$

Table 2 here

A key advantage of our module, compared to previous core HRS questions and other surveys, is that we probe further to inquire about the outcomes associated with undertaking planning and related calculations. Panel A of Table 2 indicates that only 58 percent of those who tried to develop a plan actually did so, while another handful "more 
or less” developed a plan (nine percent). Both of these groups we refer to below as the Serious Planners. The high failure rate, so far as developing a plan is concerned, underscores the fact that retirement projections are difficult to do. If we consider those who responded positively to the question, as many as half of simple planners did not succeed in developing a plan, another disappointing finding. Furthermore, of the subset of serious planners, only one-third (38 percent) was always able to stick to its plan, while half were "mostly" able to stick to their plans (below we call these respondents Successful Planners). In the sample as a whole, this represents a meager 19 percent overall rate of successful planning. Of course, households may face unexpected shocks making them deviate from plans, but the fact remains that few respondents do what the economic models suggest that they should. In other words, planning for retirement is difficult, few do it, and fewer still think they get it right.

To further evaluate what planning means and what people actually do when planning for retirement, we also asked respondents to indicate which tools they used in the process. It is possible that those who used crude or inaccurate tools were also those who had low planning success. In fact, respondents used a wide variety of tools to calculate their retirement needs (see Panel A of Table 3; note that these questions were asked only of those who reported they attempted a retirement saving calculations). Results show that between one-quarter and one-fifth of respondents talked to family/relatives or coworkers/friends, while one-third or more used formal means such as retirement calculators, retirement seminars, or financial experts. Successful Planners were more likely to use formal means (over 40 percent), whereas Simple Planners - some of whom tried and failed - tended to rely on less formal approaches. The Table also shows that 
financial literacy is correlated with planning tools, even though unevenly. The list of tools does not exhaust what people might do; in fact, as many as one quarter of the self-reported planners indicated that they did not use any of the listed tools.

\section{Table 3 here}

Those who were correct regarding compound interest and inflation were more likely to have attended a retirement seminar, suggesting that such seminars may provide information (without further control variables we cannot hold constant other background variables). Those knowledgeable about risk diversification also tend to use formal rather than informal tools for planning. Panel B of Table 3 also reveals what the correlations were between planners' levels of financial literacy and the tools they used in their planning efforts. Those who used more sophisticated tools were always more likely to get the literacy questions right, as compared to those who relied on personal communications; furthermore, the knowledge gap was relatively the greatest for the compound interest question. Panel C shows that a very large segment - almost three-quarters (74 percent) of the respondent pool - indicates that it always or mostly tracks its spending, and over half (51 percent) always or mostly tries to set spending budget targets. This is impressive given the low level of planning for retirement. It is unclear whether those undertaking the spending budget efforts did so simply to get through the month without running out of money, or whether these efforts indicate a greater sensitivity of retirement saving needs and plans.

Prior work has established that planning has important implications for wealth accumulation (Lusardi and Mitchell 2007a, 2007b). To this end, we report the distribution of total net worth across different planning types in Table 4, and emphasize that, at the 
median, planners accumulate three times the amount of wealth than non-planners. Moreover, the amount of planning also matters: Those who are able to develop a plan and those who can stick to the plan accumulate much more wealth than simple planners. Table 4 here

\section{Linking Financial Literacy and Planning}

One reason people fail to plan for retirement, or do so unsuccessfully, may be because they are financially illiterate. In this case, they may fail to appreciate the role of (or may have a hard time solving problems with) compound interest, inflation, and risk. Table 5 sheds light on the importance of financial literacy and the relationship with planning in a multivariate Probit analysis of three dependent variables: who was a planner, who developed a plan, and who was able to stick to a plan. ${ }^{7}$ Column I in each case takes on a value of 1 if the respondent was correct regarding the literacy variables (else, $=0$ ); Column II adds an indicator equal to 1 if the respondent indicated he did not know the answer to the question (else, $=0$ ); and Column III has the same dependent variable but adds controls for demographics and specifically age, race, gender, educational attainment, and a dummy for being a Baby-Boomer (Probit analysis is appropriate when the outcomes are qualitative variables; the Table reports marginal effects.)

Table 5 here

The estimates reported are interesting along several dimensions. First, financial literacy is strongly and positively associated with planning, and the results are statistically significant at conventional levels. That is, planners of all types are much more likely to give a correct answer to our basic questions about financial literacy (Column I). Second, 
knowledge about risk diversification best differentiates between sophisticated and unsophisticated respondents. Not only does it have a much larger estimated marginal effect than being able to correctly answer the interest and the inflation questions, but it also remains statistically significant even after accounting for the demographic characteristics of the respondent. Third, lack of knowledge also matters. Even with respect to those answering incorrectly, those who cannot answer the questions are much less likely to plan and to succeed in their planning effort (Column II). What appears most crucial is a lack of knowledge about interest compounding, which makes sense since basic numeracy is crucial for doing calculations about retirement saving. Columns III report estimates after controlling for demographic characteristics, and some indicators of financial literacy remain statistically significant even after we account for these factors. For example, financial literacy clearly is linked to planning above and beyond the effect of education. Accordingly, the information provided in the financial literacy variables may prove very useful in explaining the differences we observe among households in their behavior toward retirement wealth accumulation, to which we now turn.

\section{Wealth Accumulation and Financial Literacy}

If financial illiteracy leads to poor or no planning, it may also affect wealth accumulation. Lusardi (2003) finds that those who plan accumulate more wealth before retirement and are more likely to invest in stocks. Moreover, planners are more likely to experience a satisfying retirement, perhaps because they have higher financial resources to rely on after they stop working. In Table 6 (Panel A), we report estimates from a simple regression of total net worth on the three dummies measuring financial literacy and a set 
of demographic characteristics. Here wealth is defined as the sum of checking and savings accounts, certificate of deposits and other short-terms assets, bonds, stocks, other assets, housing equity, other real estate, IRAs and Keoghs, business equity, and vehicles minus all debts. ${ }^{8}$ Controls include age, sex, race, education attainment, marital status, place of birth, and income. Since the direction of causality is unclear, we estimate the model in both the full sample and also for quartiles of the wealth distribution.

\section{Table 6 here}

The results indicate that financial illiteracy is particularly pronounced among those with low income, low education, and those with low wealth holdings. Further, financial literacy is positively correlated with wealth at the bottom of the wealth distribution, which suggests that those who have basic financial knowledge are better able to save. Those having a command of basic numeracy and who understand risk diversification also have higher wealth holdings, something of a remarkable result given that we control for several of the demographic characteristics that elsewhere have been linked to low financial literacy (race, gender and low income); we also account for educational attainment.

Table 6B reports estimates from a Probit model of stock ownership. The hypothesis here is that financial literacy will be influential over portfolio choice: if investors do not understand interest compounding, inflation, or risk diversification, they are less likely to invest in complex assets such as stocks. We control for both the sociodemographics listed above and additionally add total net worth. The findings indicate a strong positive correlation between stock ownership and knowledge of risk diversification, for both the total sample and across education groups. Basic numeracy also plays a role, but mostly for those with high education (defined as having more than a high school 
degree); this is true even after accounting for education and total net worth. These findings may help explain the "puzzle" of why so few households hold stocks (Haliassos and Bertaut 1995). Moreover, they may shed light on another puzzling finding in household surveys such as the Survey of Consumer Finances. When asked how much risk respondents are willing to take, a large majority (more than 60 percent) state they are unwilling to take any financial risk. This may be due not only to strong risk aversion, but also to the fact that many respondents feel they simply do not understand risk diversification.

\section{Conclusions and Implications}

As more individuals approach and cross over the retirement threshold, it is crucial to ascertain whether they actually know how to plan for retirement and whether they seem able to execute these plans effectively. Our HRS module is informative in this regard, as it asks about people's basic financial literacy in terms of their comprehension of compound interest rates and inflation, along with the more nuanced concept of risk diversification. It is disturbing that only half of the respondents can correctly answer questions regarding interest compounding and inflation, and only one-third can correctly answer both of those two questions and a question about risk diversification. This suggests widespread financial illiteracy among older Americans. When we examine whether people tried to figure out how much they need to save for retirement, whether they devised a plan, and whether they succeeded at the plan, the news is also not good. Fewer than one-third of this cohort on the verge of retirement had ever tried to come up with a retirement plan, and only two-thirds of these succeeded. In the sample as a whole, 
fewer than one in five of these older Americans engaged in successful retirement planning.

Furthermore, we show that financial knowledge and planning are clearly interrelated, and keeping track of spending and budgeting appears conducive to retirement saving. Finally, we evaluate the planning tools people use. It is interesting that the respondents who did plan were less likely to talk to family/relatives or co-workers/friends, and more likely to use formal means such as retirement calculators, retirement seminars, or financial experts. Inasmuch as planning is an important predictor of saving and investment success, we may have uncovered an important explanation for why household wealth holdings differ, and why some people enter retirement with very low wealth (Venti and Wise 2001; Lusardi 1999; Mitchell and Moore 1998; Moore and Mitchell 2000). The empirical analysis here suggests that financial literacy can play a key role on both savings and portfolio choice.

Our work has relevance for policy in several directions. First, there has been a long-term growth in financial planning products, and service providers (Hung, Clancy, and Dominitz 2011). Also governments and nonprofits have sponsored programs to spur financial education, and employers are increasingly offering retirement seminars to their workers as well (Clark, Morrill, and Allen 2011; Clark and D’Ambrosio 2002; Clark et al. 2003, 2004; Collins 2011). While some researchers suggest that such programs will have only minimal effects on saving, our work suggests that this may be due to the lack of welltargeted content. For example, if financial illiteracy is widespread among particular subsets of employees, a one-time financial education lesson may be insufficient to influence planning and saving decisions. Conversely, education programs targeted 
specifically to particular subgroups may be better suited to address substantial differences in preferences and saving needs.

\section{Acknowledgements}

The research reported herein was pursuant to a grant from the US Social Security Administration (SSA) funded as part of the Retirement Research Consortium (RRC) and the Pension Research Council/Boettner Center at the Wharton School. Without implicating them, we are grateful for comments provided by Alberto Alesina, Rob Alessie, Maristella Botticini, John Campbell, Andrew Caplin, Sewin Chan, Gary Engelhardt, Alan Gustman, Mike Hurd, Arie Kapteyn, Mauro Mastrogiacomo, Mary Beth Ofstedal, William Rodgers, Chris Snyder, Maarten van Rooij, Arthur van Soest, and Steve Utkus. Helpful suggestions were offered by participants at conference at Dartmouth, Harvard, Rand, the NBER, the Retirement Research Consortium, the Dutch Central Bank, and the American Economic Association. Mark Christman and Jason Beeler provided excellent research assistance. Opinions and errors are solely those of the authors and not of the institutions with whom the authors are affiliated. Findings and conclusions do not represent the views of the SSA, any agency of the Federal Government, or the RRC. 


\section{References}

Agnew, Julie and Lisa Szykman (2005). “Asset Allocation and Information Overload: The Influence of Information Display, Asset Choice and Investor Experience.” Journal of Behavioral Finance 6: 57-70.

Ameriks, John, Andrew Caplin and John Leahy (2003). "Wealth Accumulation and the Propensity to Plan”. Quarterly Journal of Economics 68: 1007-1047.

Ameriks, John, Andrew Caplin, and John Leahy (2004). “The Absent-Minded Consumer.” NBER Working Paper 10216.

Bernheim, Douglas (1995). “Do Households Appreciate their Financial Vulnerabilities? An Analysis of Actions, Perceptions, and Public Policy,” in Tax Policy and Economic Growth. Washington, DC: American Council for Capital Formation, pp. $1-30$

Bernheim, Douglas (1998). “Financial Illiteracy, Education, and Retirement Saving,” in O.S. Mitchell and S. Schieber, eds., Living with Defined Contribution Pensions. Philadelphia, PA: University of Pennsylvania Press, pp. 38-68.

Calvert, Laurent, John Campbell and Paolo Sodini (2007). “Down or Out: Assessing the Welfare Costs of Household Investment Mistakes.” Journal of Political Economy 115: 707-747.

Campbell, John (2006). “Household Finance,” Journal of Finance, 61(4): 1553-1604.

Chan, Sewin and Ann Huff Stevens (2003). “What You Don’t Know Can’t Help You: Knowledge and Retirement Decision Making.” New York University Working Paper. 
Christelis, Dimitris, Tullio Jappelli, and Mario Padula (2005). “Health Risk, Financial Information and Social Interaction: the Portfolio Choice of European Elderly Households”. University of Salerno Working Paper.

Clark, Robert, and Madeleine D’Ambrosio (2002). “Saving for Retirement: The Role of Financial Education.” TIAA-CREF Institute Working paper 4-070102-A.

Clark, Robert, Madeleine D’Ambrosio, Ann McDermed, and Kshama Sawant (2003). “Financial Education and Retirement Saving.” TIAA-CREF Institute Working Paper 11-020103.

Clark, Robert, Madeleine D’Ambrosio, Ann McDermed, and Kshama Sawant (2004). “Sex Differences, Financial Education and Retirement Goals” in O.S. Mitchell and S. Utkus, eds., Pension Design and Structure: New Lessons from Behavioral Finance. Oxford: Oxford University Press, pp. 185-206.

Clark, Robert L., Melinda S. Morrill, and Steven G. Allen (2011). ‘Pension Plan Distributions: The Importance of Financial Literacy,’ in O.S. Mitchell and A. Lusardi, eds., Financial Literacy: Implications for Retirement Security and the Financial Marketplace. Oxford: Oxford University Press.

Collins, J. Michael (2011). 'Improving Financial Literacy: The Role of Nonprofit Providers,' in O.S. Mitchell and A. Lusardi, eds., Financial Literacy: Implications for Retirement Security and the Financial Marketplace. Oxford: Oxford University Press.

Duflo, Esther and Emmanuel Saez (2003). “The Role of Information and Social Interactions in Retirement Plan Decisions: Evidence from a Randomized Experiment”. Quarterly Journal of Economics 118: 815-842. 
Duflo, Esther and Emmanuel Saez (2004). "Implications of Pension Plan Features, Information, and Social Interactions for Retirement Saving Decisions,” in O.S. Mitchell and S. Utkus, eds., Pension Design and Structure: New Lessons from Behavioral Finance. Oxford: Oxford University Press: pp. 137-153.

Employee Benefits Research Institute (EBRI) (1996). "Participant Education: Actions and Outcomes”. EBRI Issue Brief 169. January.

Employee Benefits Research Institute (EBRI) (2001). "Retirement Confidence Survey (RCS), Minority RCS, and Small Employer Retirement Survey”. EBRI Issue Brief 234. June.

Gustman, Alan and Tom Steinmeier (1999). "Effects of Pensions on Savings: Analysis with Data from the Health and Retirement Study”. Carnegie-Rochester Conference Series on Public Policy 50: 271-324.

Gustman, Alan and Tom Steinmeier (2004). “What People Don’t Know about their Pensions and Social Security.” In Private Pensions and Public Policies. Edited by William Gale, John Shoven and Mark Warshawsky, Washington, DC: Brookings Institution: 57-125.

Haliassos, Michael and Carol Bertaut (1995). “Why Do So Few Hold Stocks?” Economic Journal, 105: 1110-1129.

Hilgert, Marianne, Jeanne Hogarth, and Sondra Beverly (2003). "Household Financial Management: The Connection between Knowledge and Behavior," Federal Reserve Bulletin, 309-322.

Hogarth, Jeanne, Chris Anguelov, and Jinkook Lee (2004). “Why Don’t Households Have A Checking Account?” The Journal of Consumer Affairs, 38: 1-34. 
Hogarth, Jeanne and Marianne Hilgert (2002). "Financial Knowledge, Experience and Learning Preferences: Preliminary Results from a New Survey on Financial Literacy," Consumer Interest Annual, 48.

Hung, Angela A., Noreen Clancy, and Jeff Dominitz (2011). 'Investor Knowledge and Experience with Investment Advisers and Broker-Dealers,' in O.S. Mitchell and A. Lusardi, eds., Financial Literacy: Implications for Retirement Security and the Financial Marketplace. Oxford: Oxford University Press.

Lusardi, Annamaria (1999). “Information, Expectations, and Savings for Retirement,” in H. Aaron, ed., Behavioral Dimensions of Retirement Economics. Washington, DC: Brookings Institution Press and Russell Sage Foundation: pp. 81-116.

Lusardi, Annamaria (2002). “Preparing for Retirement: The Importance of Planning Costs”. National Tax Association Proceedings 2002: 148-154.

Lusardi, Annamaria (2003). “Planning and Saving for Retirement”. Dartmouth College Working Paper.

Lusardi, Annamaria and Olivia S. Mitchell (2007a). “Baby Boomer Retirement Security: The Roles of Planning, Financial Literacy, and Housing Wealth.” Journal of Monetary Economics. 54(1) January: 205-224.

Lusardi, Annamaria and Olivia S. Mitchell (2007b). “Financial Literacy and Retirement Planning: New Evidence from the RAND American Life Panel.” NBER Working Paper.

Lusardi, Annamaria and Olivia S. Mitchell (2007c). "Financial Literacy and Retirement Preparedness: Evidence and Implications for Financial Education.” Business Economics 42, 35-44. 
Lusardi, Annamaria and Olivia S. Mitchell (2008). "Planning and Financial Literacy: How Do Women Fare?” American Economic Review P\&P: 98:2, 413-417

Lusardi, Annamaria and Olivia S. Mitchell (2009). “How Ordinary Consumers Make Complex Economic Decisions: Financial Literacy and Retirement Readiness.” NBER Working Paper 15350.

Lusardi, Annamaria, Olivia S. Mitchell, and Vilsa Curto (2010). “Financial Literacy among the Young: Evidence and Implications for Consumer Policy.” Journal of Consumer Affairs. (44, 2): 358-380.

Mandell, Lewis (2004). Financial Literacy: Are We Improving? Washington, D.C.: Jump\$tart Coalition for Personal Financial Literacy.

Mastrobuoni, Giovanni (2005). “Do Better-Informed Workers Make Better Retirement Choice? A Test Based on the Social Security Statement.” Princeton University Working Paper.

Miles, David (2004). The UK Mortgage Market: Taking a Longer-Term View. London: UK Treasury.

Mitchell, Olivia (1988). “Worker Knowledge of Pensions Provisions.” Journal of Labor Economics 6: 28-29.

Mitchell, Olivia S. and James Moore (1998). “Can Americans Afford to Retire? New Evidence on Retirement Saving Adequacy.” Journal of Risk and Insurance 65: $371-400$.

Moore, Danna (2003). “Survey of Financial Literacy in Washington State: Knowledge, Behavior, Attitudes, and Experiences.” Social and Economic Sciences Research Center Technical Report 03-39, Washington State University. 
Moore, James, and Olivia S. Mitchell (2000). “Projected Retirement Wealth and Saving Adequacy,” in O.S. Mitchell, B. Hammond, and A. Rappaport, eds., Forecasting Retirement Needs and Retirement Wealth. Philadelphia, PA: University of Pennsylvania Press, pp. 68-94.

National Council on Economic Education (NCEE) (2005). What American Teens and Adults Know About Economics. Washington, DC: NCEE.

Venti, Steven and David Wise (2001). “Choice, Chance, and Wealth Dispersion at Retirement,” in S. Ogura, T. Tachibanaki, and D. Wise, eds., Aging Issues in the United States and Japan. Chicago, IL: University of Chicago Press, pp. 25-64. Yakoboski, Paul and Jennifer Dickemper (1997). “Increased Saving but Little Planning. Results of the 1997 Retirement Confidence Survey”. EBRI Issue Brief 191. Washington, D.C.: EBRI. 


\section{Endnotes}

${ }^{1}$ See Campbell (2006) for an excellent discussion of the myriad problems households face when making financial decisions.

${ }^{2}$ In conventional economic models, assets in the last period of life will not exceed zero and the consumer does not die in debt.

${ }^{3}$ Other surveys also find similar results concerning knowledge regarding properties of bonds, stocks, and mutual funds (c.f. Agnew and Szykman 2005)

${ }^{4}$ Similar findings are found internationally; for instance, Miles (2004) shows that U.K. borrowers also display poor understanding of mortgages and interest rates, and Christelis, Jappelli, and Padula (2005) use SHARE surveys from several European countries to show that these respondents also score low on financial numeracy and literacy scales.

${ }^{5}$ For brevity we exclude other minority groups and exclude those who do not answer the questions (a small group).

${ }^{6}$ There is also evidence that knowledge about pensions and Social Security affects retirement decisions; see Chan and Huff Stevens (2003); Duflo and Saez (2003, 2004); and Mastrobuoni (2005).

${ }^{7}$ It is possible that causality may also go the other way: that is, those who plan may also become more financially literate and develop the ability to do retirement calculations; for discussion of endogeneity considerations, see Lusardi and Mitchell (2007a).

${ }^{8}$ The analysis herein uses the 2004 wealth data that included imputes for those who did not report assets or debt. 


\section{Table 1. Financial Literacy Patterns}

(Source: Authors' calculations based on 2004 Health and Retirement Survey, Planning Module unweighted data)

Panel A: Distribution of Responses to Financial Literacy Questions

\begin{tabular}{|l|cccc|}
\hline \multirow{2}{*}{} & \multicolumn{4}{|c|}{ Responses } \\
\cline { 2 - 5 } & Correct & Incorrect & DK & Refuse \\
\hline \multirow{2}{*}{ Compound Interest } & $67.1 \%$ & $22.2 \%$ & $9.4 \%$ & $1.3 \%$ \\
Inflation & $75.2 \%$ & $13.4 \%$ & $9.9 \%$ & $1.5 \%$ \\
Stock Risk & $52.3 \%$ & $13.2 \%$ & $33.7 \%$ & $0.9 \%$ \\
\hline
\end{tabular}

Panel B: Joint Probabilities of Being Correct to Financial Literacy Questions

\begin{tabular}{|l|cccc|}
\hline & $\begin{array}{c}\text { All 3 responses } \\
\text { correct }\end{array}$ & $\begin{array}{c}\text { Only 2 responses } \\
\text { correct }\end{array}$ & $\begin{array}{c}\text { Only 1 response } \\
\text { correct }\end{array}$ & $\begin{array}{c}\text { No responses } \\
\text { correct }\end{array}$ \\
\hline & $34.3 \%$ & $35.8 \%$ & $16.3 \%$ & $9.9 \%$ \\
\hline
\end{tabular}

Note: DK = respondent indicated “don’t know 
Table 2. Prevalence of Retirement Planning Calculations

(Source: Authors' calculations based on 2004 Health and Retirement Survey, Planning Module unweighted data)

Panel A. Proportion of Planners in Respective Sub-Groups

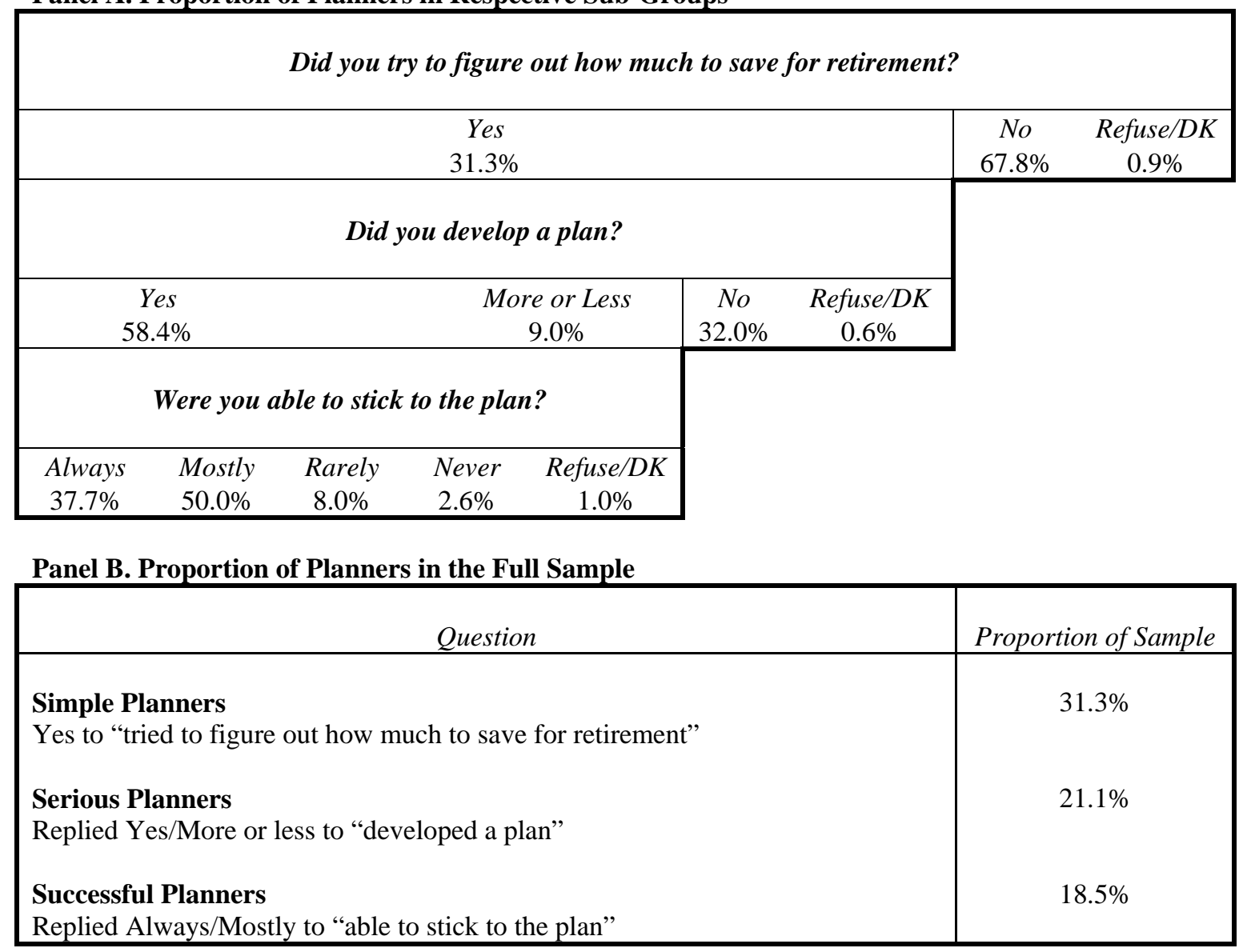


Table 3. Links between Planning Tools, Planning Success, and Financial Literacy (Source: Authors' calculations based on 2004 Health and Retirement Survey, Planning Module unweighted data)

Panel A: Tools Planners Report Using

\begin{tabular}{|l|cc|}
\hline Tools & Simple Planners & Successful Planners \\
& $n=397$ & 235 \\
\hline & & $17.4 \%$ \\
Talk to family/friends & $21.1 \%$ & $(.380)$ \\
Talk to coworkers/friends & $(.409)$ & $21.3 \%$ \\
& & $(.410)$ \\
Attend retirement seminar & $24.7 \%$ & $40.4 \%$ \\
& $(.432)$ & $(.492)$ \\
Use calculator/worksheet & $35.3 \%$ & $43.4 \%$ \\
& $(.479)$ & $(.497)$ \\
Consult financial planner & & $49.4 \%$ \\
& $(.485)$ & $(.501)$ \\
\hline
\end{tabular}

Panel B: Correlation Between Planning, Tools Used, and Financial Literacy

\begin{tabular}{|l|c|ccccc|}
\hline & $\begin{array}{c}\text { Simple } \\
\text { Planners }\end{array}$ & $\begin{array}{c}\text { Talk to } \\
\text { family/ } \\
\text { friends } \\
n=84\end{array}$ & $\begin{array}{c}\text { Talk to } \\
\text { coworkers/ } \\
\text { friends } \\
n=98\end{array}$ & $\begin{array}{c}\text { Attend } \\
\text { retirement } \\
\text { seminar } \\
n=140\end{array}$ & $\begin{array}{c}\text { Use } \\
\text { calculator/ } \\
\text { worksheet } \\
n=150\end{array}$ & $\begin{array}{c}\text { Consult } \\
\text { financial } \\
\text { planner } \\
n=155\end{array}$ \\
\hline $\begin{array}{l}\text { Correct on Compound } \\
\text { Interest }\end{array}$ & $75.3 \%$ & $65.5 \%$ & $69.4 \%$ & $77.9 \%$ & $83.3 \%$ & $80.6 \%$ \\
Correct on Inflation & $84.4 \%$ & $82.1 \%$ & $88.8 \%$ & $88.6 \%$ & $89.3 \%$ & $86.5 \%$ \\
Correct on Stock Risk & $52.2 \%$ & $65.5 \%$ & $71.4 \%$ & $80.0 \%$ & $79.3 \%$ & $73.5 \%$ \\
\hline
\end{tabular}

Panel C. Budgeting Questions: All Respondents

\begin{tabular}{|l|cc|ccc|}
\hline & Always & Mostly & Rarely & Never & $\begin{array}{c}\text { Do not } \\
\text { know/Refuse }\end{array}$ \\
\hline Track spending & $43.2 \%$ & $30.8 \%$ & $14.7 \%$ & $11.0 \%$ & $0.3 \%$ \\
Set spending budget & $23.6 \%$ & $27.6 \%$ & $22.4 \%$ & $26.0 \%$ & $0.5 \%$ \\
\hline
\end{tabular}


Table 4. Planning and Wealth Holdings

(Source: Authors' calculations based on 2004 Health and Retirement Survey, Planning Module unweighted data)

\begin{tabular}{|l|c|c|c|c|}
\hline & Non-Planners & \multicolumn{3}{|c|}{ Planners } \\
\hline & & Simple Planners & Serious Planners & Successful Planners \\
\hline 25th percentile & 30,400 & 107,750 & 171,000 & 197,500 \\
\hline Median & 122,000 & 307,750 & 370,000 & 410,000 \\
\hline 75 th percentile & 334,500 & 641,000 & 715,000 & 781,500 \\
\hline Mean & 338,418 & 742,843 & 910,382 & $1,002,975$ \\
\hline
\end{tabular}

Note: This table reports the distribution of total net worth across different planning types. Simple Planners are those who tried to calculate how much they need to save for retirement; Serious Planners are those who were able to develop a saving plan; Successful Planners are those who were able to stick to their saving plan. The total number of observations is 1,269 . 
Table 5. Probit Analysis of Simple, Serious, and Successful Planners: Marginal effects reported (Source: Authors' calculations based on 2004 Health and Retirement Survey, Planning Module - unweighted data)

\begin{tabular}{|c|c|c|c|c|c|c|c|c|c|}
\hline & \multicolumn{3}{|c|}{$\begin{array}{c}\text { Simple Planners } \\
\mathrm{n}=1269\end{array}$} & \multicolumn{3}{|c|}{$\begin{array}{c}\text { Serious Planners } \\
\mathrm{n}=1269\end{array}$} & \multicolumn{3}{|c|}{$\begin{array}{c}\text { Successful Planners } \\
\mathrm{n}=1269\end{array}$} \\
\hline & $\mathbf{I}$ & II & III & $\mathbf{I}$ & II & III & $\mathbf{I}$ & II & III \\
\hline Correct on Compound Interest & $\begin{array}{l}.068 * * \\
(.028)\end{array}$ & $\begin{array}{l}.032 \\
(.031)\end{array}$ & $\begin{array}{l}.024 \\
(.032)\end{array}$ & $\begin{array}{l}.064^{* *} \\
(.024)\end{array}$ & $\begin{array}{l}.037 \\
(.025)\end{array}$ & $\begin{array}{l}.004 \\
(.027)\end{array}$ & $\begin{array}{l}.061^{* *} \\
(.022)\end{array}$ & $\begin{array}{l}.037 \\
(.024)\end{array}$ & $\begin{array}{l}.007 \\
(.024)\end{array}$ \\
\hline Correct on Inflation & $\begin{array}{c}.104^{* * *} \\
(.03)\end{array}$ & $\begin{array}{l}.079 * * \\
(.035)\end{array}$ & $\begin{array}{l}.053 \\
(.037)\end{array}$ & $\begin{array}{c}.073 * * * \\
(.026)\end{array}$ & $\begin{array}{l}.057^{*} \\
(.029)\end{array}$ & $\begin{array}{l}.038 \\
(.030)\end{array}$ & $\begin{array}{c}.072 * * * \\
(.024)\end{array}$ & $\begin{array}{l}.062 * * \\
(.027)\end{array}$ & $\begin{array}{l}.043 \\
(.027)\end{array}$ \\
\hline Correct on Stock Risk & $\begin{array}{c}.165^{* * * *} \\
(.026) \\
\end{array}$ & $\begin{array}{c}.109 * * * \\
(.038) \\
\end{array}$ & $\begin{array}{c}.094 * * * \\
(.038) \\
\end{array}$ & $\begin{array}{c}.155^{* * * *} \\
(.022) \\
\end{array}$ & $\begin{array}{c}.101^{* * * *} \\
(.032) \\
\end{array}$ & $\begin{array}{c}.086^{* * * *} \\
(.032)\end{array}$ & $\begin{array}{c}.137 * * * \\
(.021) \\
\end{array}$ & $\begin{array}{c}.088 * * * \\
(.031) \\
\end{array}$ & $\begin{array}{c}.067 * * * \\
(.029) \\
\end{array}$ \\
\hline DK Compound Interest & & $\begin{array}{c}-.171^{* *} \\
(.056)\end{array}$ & $\begin{array}{c}-.162 * * * \\
(.056)\end{array}$ & & $\begin{array}{c}-.138 * * \\
(.042)\end{array}$ & $\begin{array}{c}-.127 * * \\
(.040)\end{array}$ & & $\begin{array}{c}-.130 * * \\
(.036)\end{array}$ & $\begin{array}{c}-.117 * * \\
(.032)\end{array}$ \\
\hline DK Inflation & & $\begin{array}{l}.025 \\
(.080)\end{array}$ & $\begin{array}{l}.035 \\
(.081)\end{array}$ & & $\begin{array}{l}.036 \\
(.077)\end{array}$ & $\begin{array}{l}.047 \\
(.078)\end{array}$ & & $\begin{array}{c}.057 \\
(.078)\end{array}$ & $\begin{array}{l}.068 \\
(.079)\end{array}$ \\
\hline DK Stock Risk & & $\begin{array}{c}-.071^{*} \\
(.042)\end{array}$ & $\begin{array}{c}-.044 \\
(.043) \\
\end{array}$ & & $\begin{array}{c}-.070 * \\
(.035)\end{array}$ & $\begin{array}{c}-.044 \\
(.036)\end{array}$ & & $\begin{array}{c}-.064^{*} \\
(.033) \\
\end{array}$ & $\begin{array}{c}-.038 \\
(.033) \\
\end{array}$ \\
\hline Demographics & no & no & yes & no & no & yes & no & no & yes \\
\hline Pseudo $\mathrm{R}^{2}$ & .048 & .056 & .107 & .060 & .069 & .133 & .060 & .069 & .142 \\
\hline
\end{tabular}

* estimated coefficient significant at the $10 \%$ level; ** estimated coefficient significant at the $5 \%$ level; *** estimated coefficient significant at the $1 \%$ level. 
Table 6A. Wealth Accumulation and Financial Literacy: OLS and Quantile Regressions

(Source: Authors' calculations based on 2004 Health and Retirement Survey, Planning Module - unweighted data; Wealth is divided by 1,000$)$

\begin{tabular}{|c|c|c|c|c|}
\hline & Total sample & $1^{\text {st }}$ quartile & Median & 3rd quartile \\
\hline $\begin{array}{l}\text { Correct on Compound } \\
\text { interest }\end{array}$ & $\begin{array}{c}40.85 \\
(25.66)\end{array}$ & $\begin{array}{c}19.72 \\
(16.91)\end{array}$ & $\begin{array}{c}29.18^{* * *} \\
(10.43)\end{array}$ & $\begin{array}{c}21.29 \\
(27.28)\end{array}$ \\
\hline Correct on Inflation & $\begin{array}{c}31.23 \\
(27.71)\end{array}$ & $\begin{array}{c}3.44 \\
(7.54)\end{array}$ & $\begin{array}{c}17.96 \\
(11.28)\end{array}$ & $\begin{array}{c}34.51 \\
(29.39)\end{array}$ \\
\hline Correct on Stock Risk & $\begin{array}{c}11.68 \\
(23.79)\end{array}$ & $\begin{array}{c}19.39 * * * \\
(6.44)\end{array}$ & $\begin{array}{c}26.95 * * * \\
(9.67)\end{array}$ & $\begin{array}{l}20.73 \\
(26.31)\end{array}$ \\
\hline Demographics & yes & yes & yes & yes \\
\hline Adjusted or Pseudo $\mathrm{R}^{2}$ & 0.32 & 0.14 & 0.20 & 0.24 \\
\hline
\end{tabular}

* estimated coefficient significant at the $10 \%$ level; ** estimated coefficient significant at the $5 \%$ level;

*** estimated coefficient significant at the $1 \%$ level.

Table 6B. Probit Analysis of Stock Ownership: Marginal effects reported

(Source: Authors' calculations based on 2004 Health and Retirement Survey, Planning Module - unweighted data)

\begin{tabular}{|l|c|c|c|}
\hline & Total sample & Low education & High education \\
\hline Correct on Compound interest & $.064^{* *}$ & .041 & $.101^{*}$ \\
& $(.030)$ & $(.030)$ & $.051)$ \\
\hline Correct on Inflation & .035 & .001 & $(.057)$ \\
\hline Correct on Stock Risk & $(.033)$ & $(.037)$ & $.202^{* * *}$ \\
& $.121^{* * *}$ & $.077 * *$ & $(.042)$ \\
\hline Demographics and wealth & $(.027)$ & $(.032)$ & yes \\
\hline Pseudo $\mathrm{R}^{2}$ & yes & 0.257 & 0.168 \\
\hline
\end{tabular}

* estimated coefficient significant at the $10 \%$ level; ** estimated coefficient significant at the $5 \%$ level;

*** estimated coefficient significant at the $1 \%$ level. 

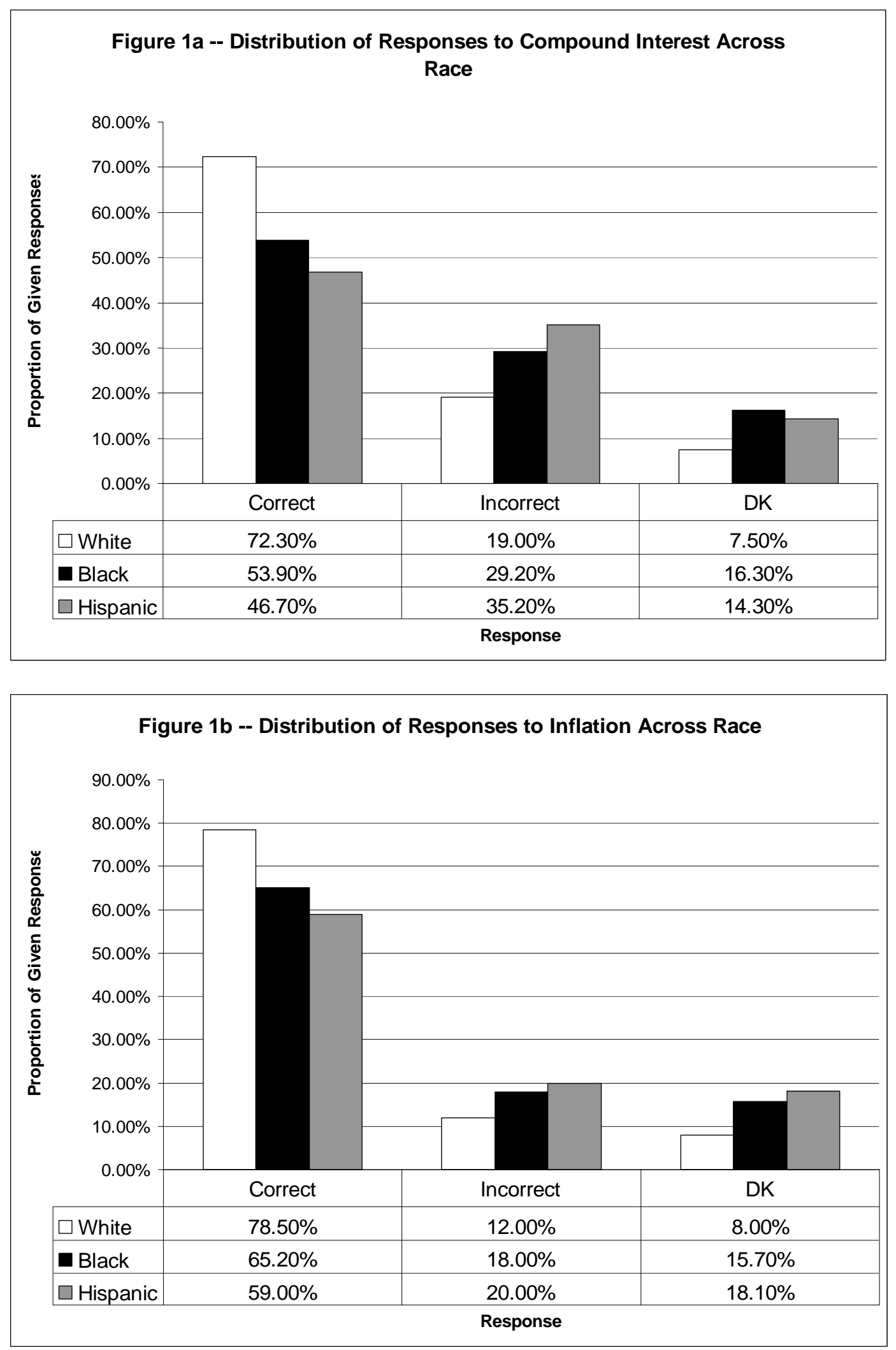


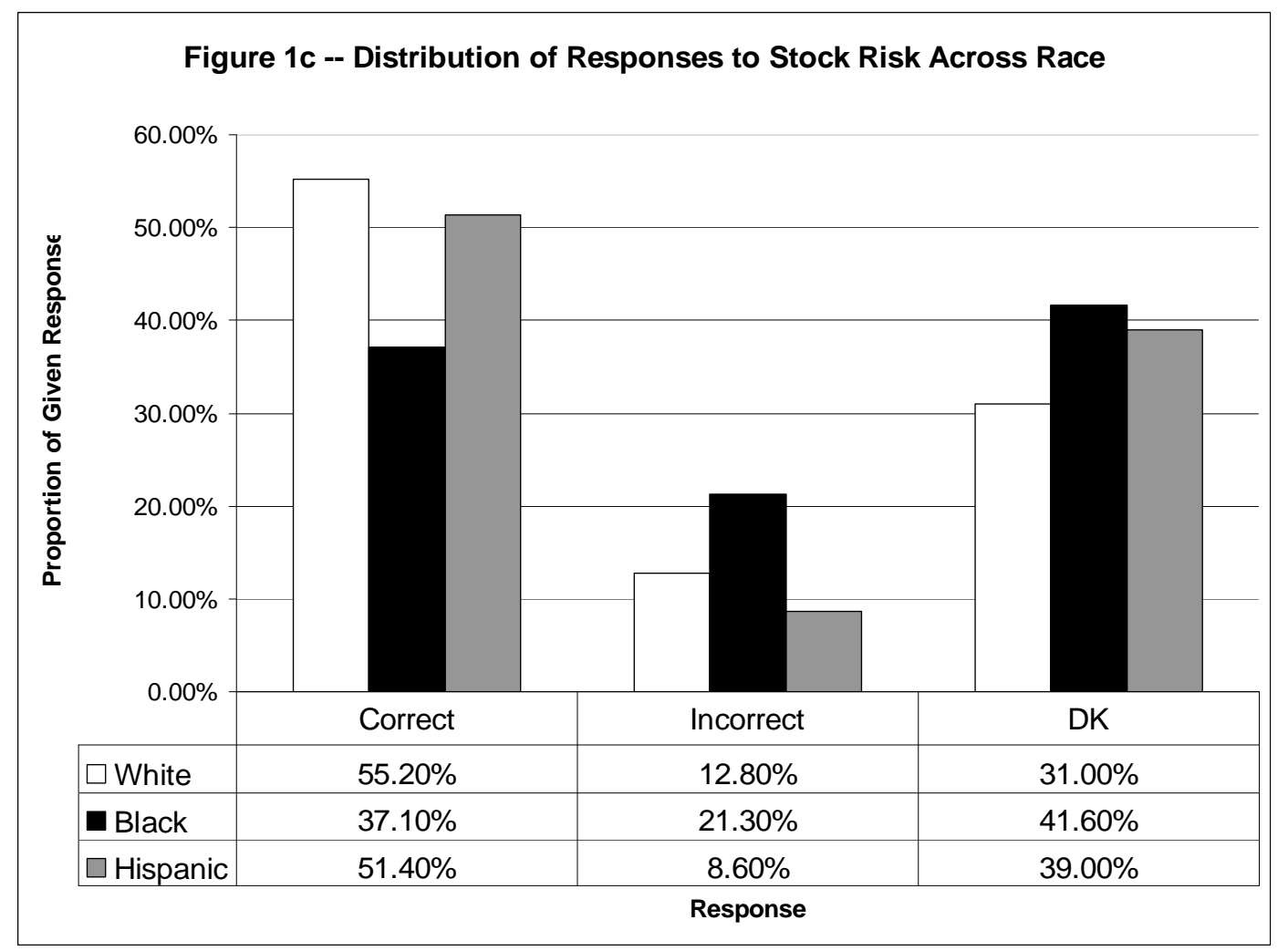

(Source: Authors' calculations based on 2004 Health and Retirement Survey, Planning Module unweighted data) 


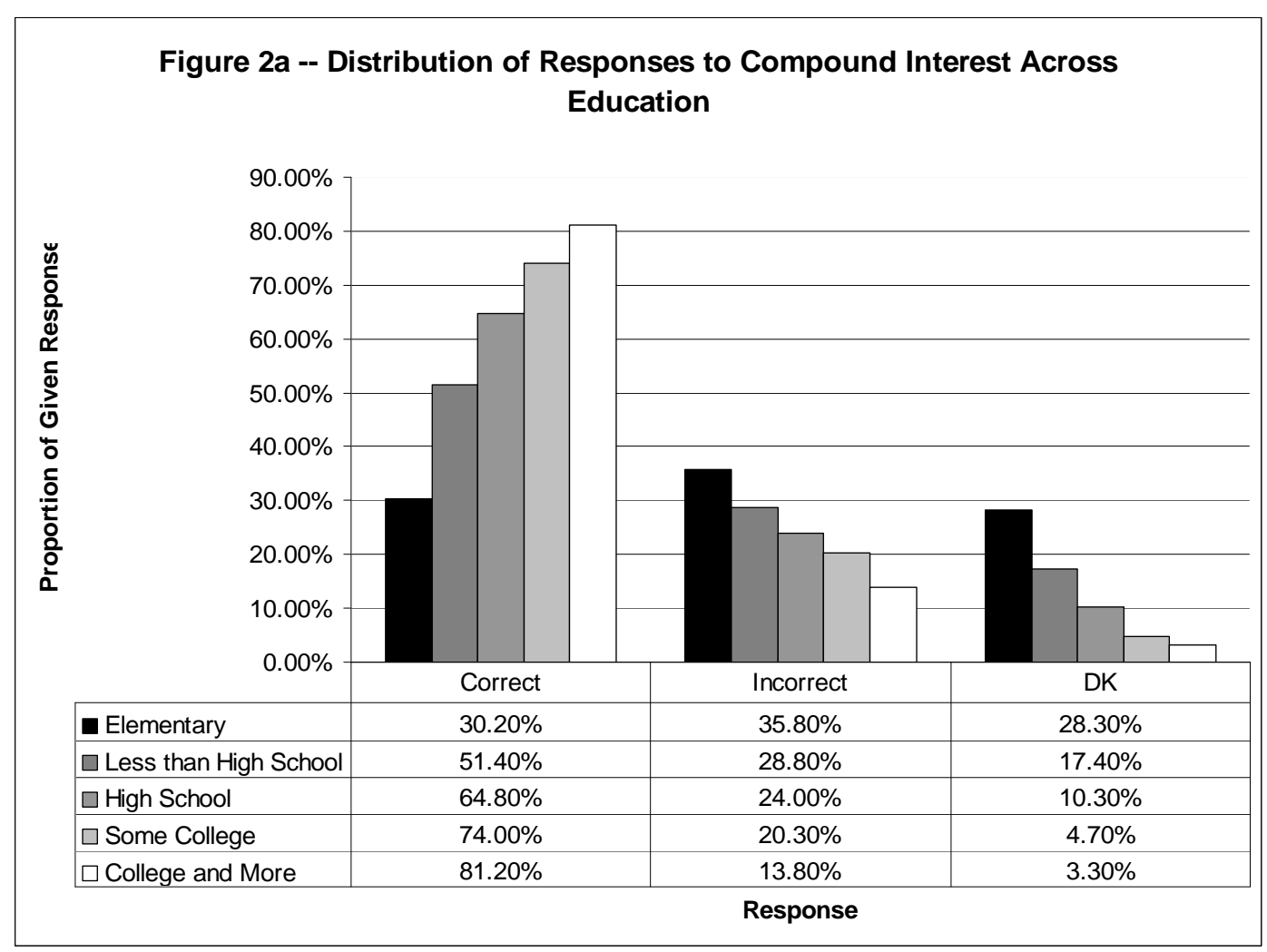


Figure $2 b$-- Distribution of Responses to Inflation Across Education

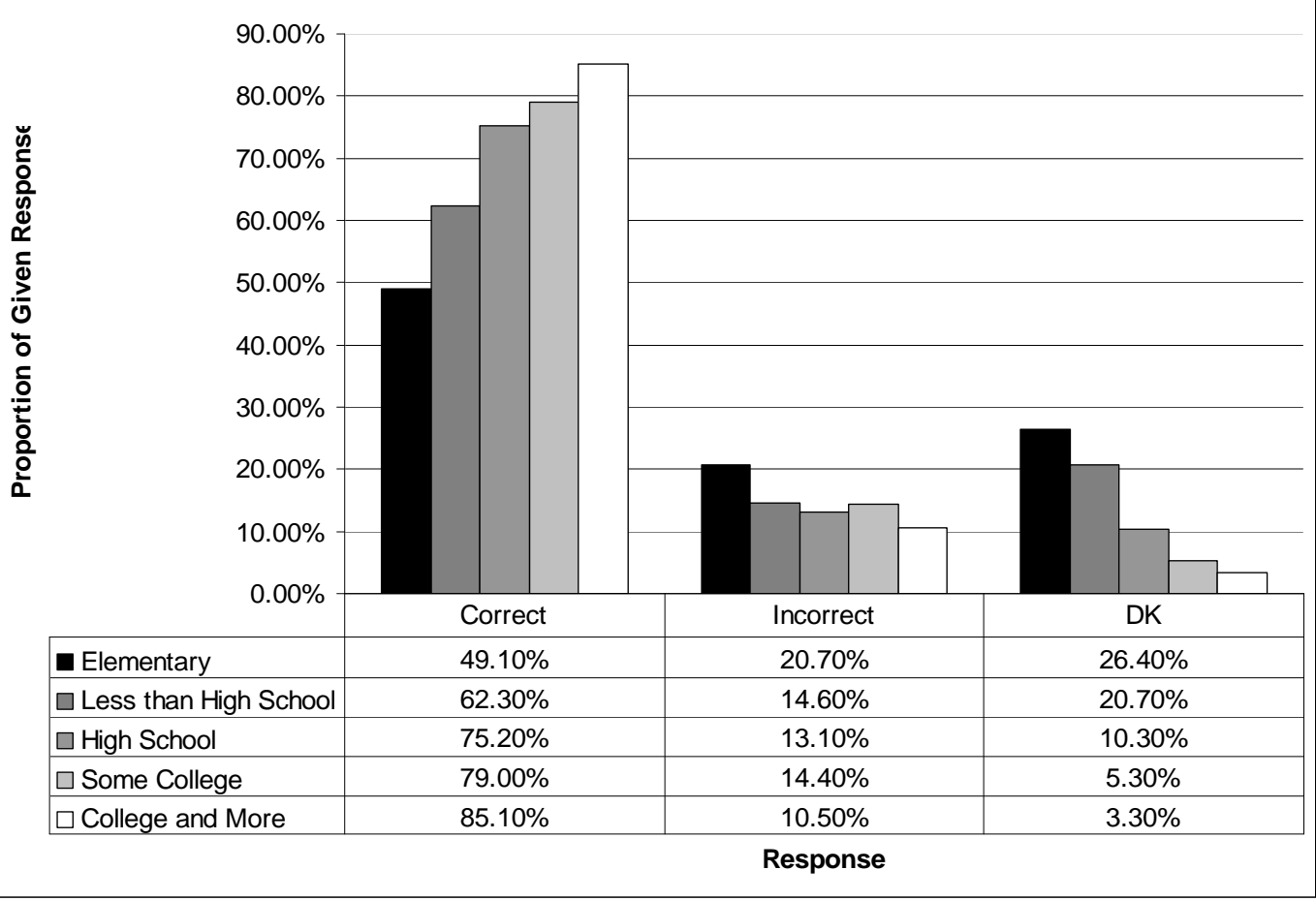

Figure 2c -- Distribution of Responses to Stock Risk Across Education

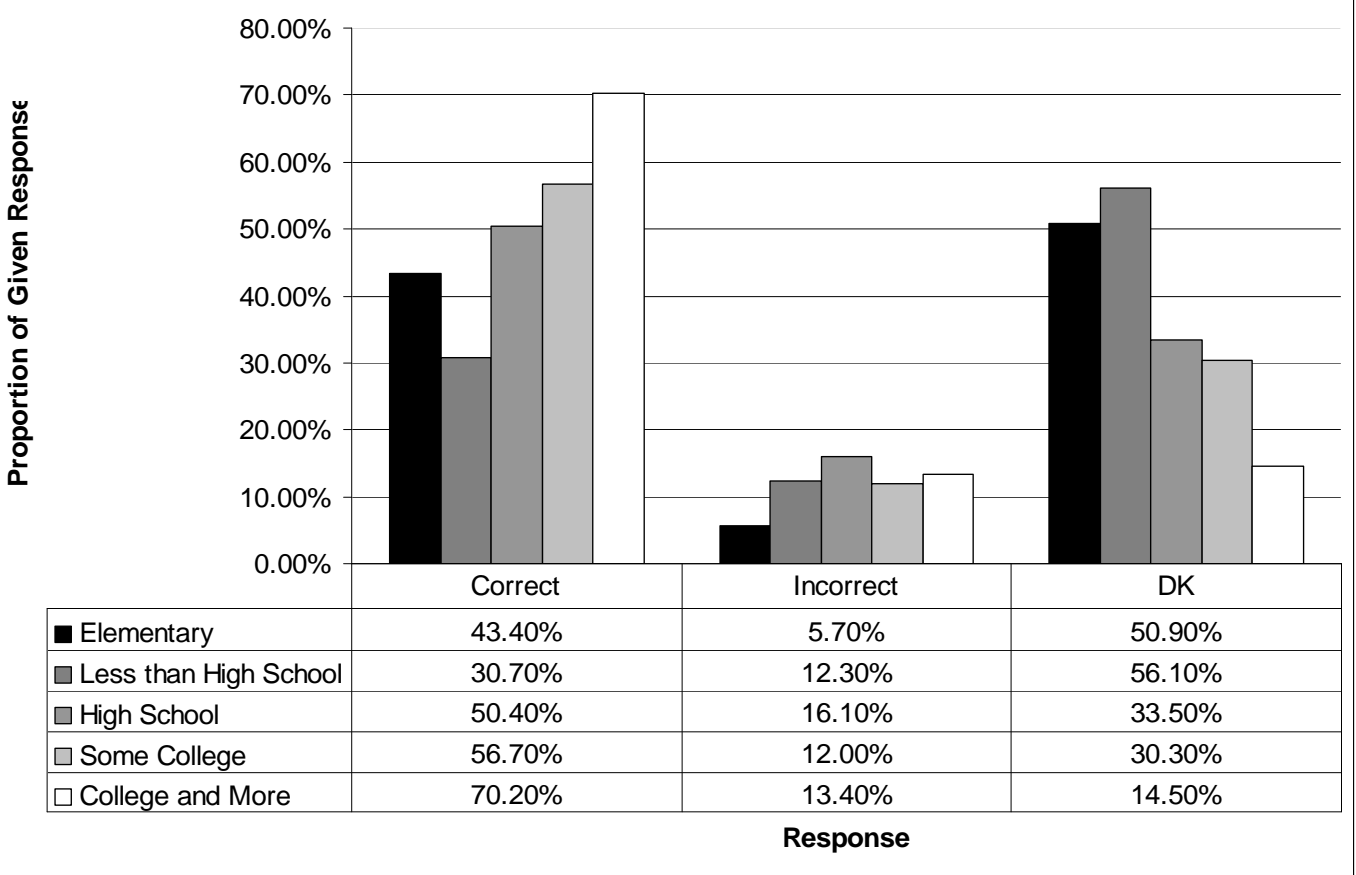


(Source: Authors' calculations based on 2004 Health and Retirement Survey, Planning Module unweighted data) 


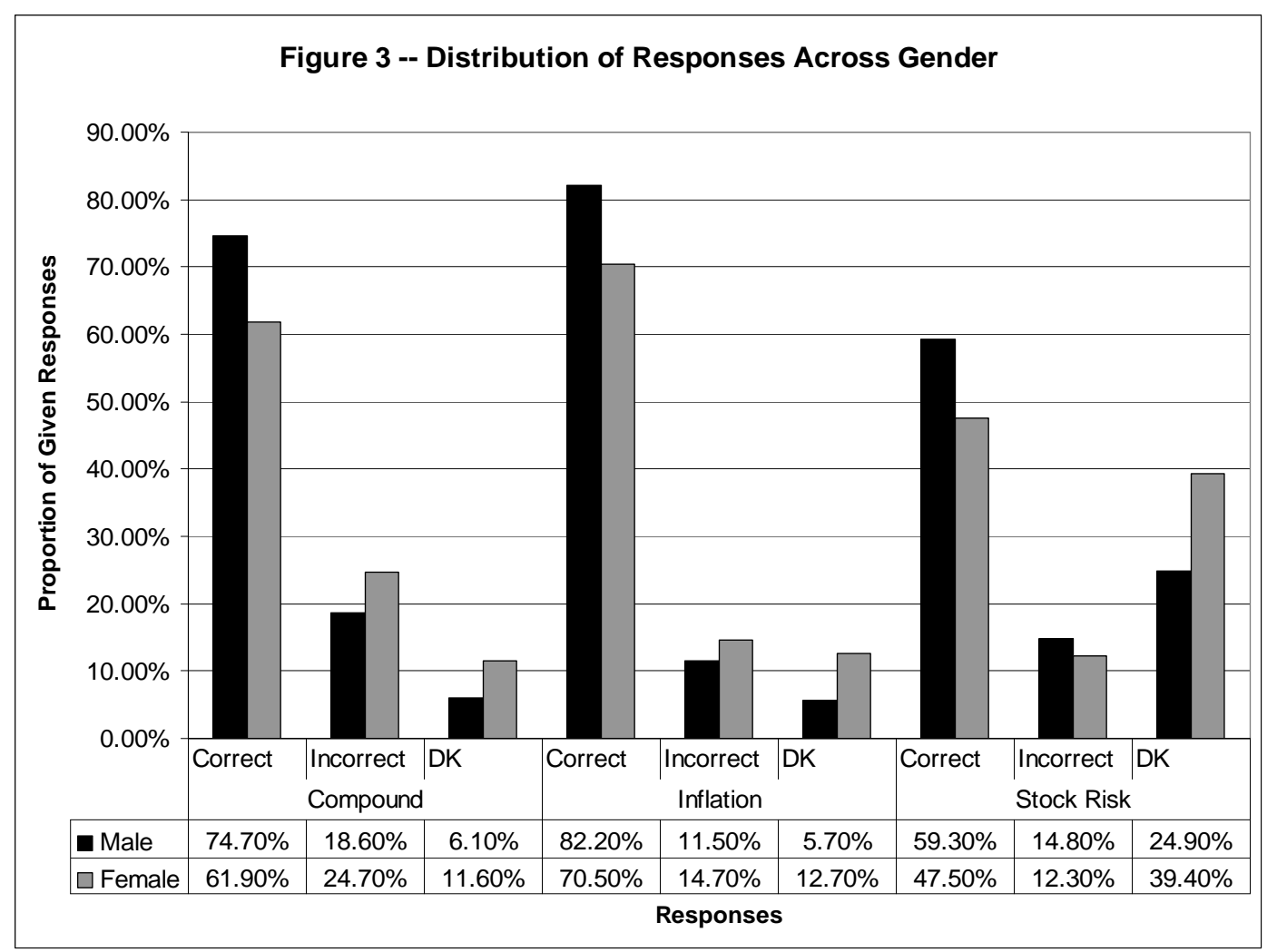

(Source: Authors' calculations based on 2004 Health and Retirement Survey, Planning Module unweighted data) 